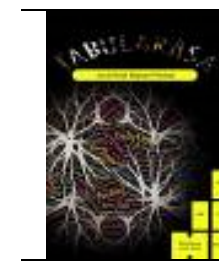

Tabularasa: Jurnal Ilmiah Magister Psikologi, 2(1) 2020: 40-47

DOI:

Tabularasa: Jurnal Ilmiah Magister Psikologi

Available online http://iurnalmahasiswa.uma.ac.id/index.php/tabularasa

\title{
Hubungan antara Kepercayaan Diri dan Dukungan Orangtua dengan Kemandirian Belajar Siswa di SMA Dharma Pancasila Medan
}

\section{Relationship Between Self-Trust and Parent Support by Student Learning Study In SMA Dharma Pancasila Medan}

\author{
Rinda Ariati Nasution1), Syaiful Akhyar2) \& Azhar Aziz'3) \\ 1) Program Studi Magister Psikologi , Pascasarjana, Universitas Medan Area, Indonesia \\ 2) Universitas Islam Negeri Sumatera Utara, Indonesia \\ 3) Fakultas Psikologi, Universitas Medan Area, Indonesia
}

\begin{abstract}
Abstrak
Tujuan dari penelitian ini adalah untuk mengetahui hubungan kepercayaan diri dan dukungan orangtua dengan kemandirian belajar siswa di SMA Dharma Pancasila Medan. Penelitian ini adalah penelitian deskriptif kuantitatif. Populasi penelitian adalah siswa SMA Dharma Pancasila Medan sebanyak 472 siswa terdiri dari kelas X sebanyak 4 kelas, kelas XI sebanyak 5 kelas, dan kelas XII sebanyak 5 kelas. Dengan menggunakan Teknik Random Sampling diperoleh sampel sebesar 120 responden. Hasil analisis deskriptif menunjukkan bahwa secara umum kondisi kepercayaan diri, dukungan orangtua dan kemandirian belajar siswa-siswi SMA Dharma Pancasila tergolong tinggi. Hasil analisis regresi berganda hipotesis pertama menunjukkan bahwa ada hubungan positif dan signifikan antara kepercayaan diri dengan kemandirian belajar, kontribusi sebesar 27,7\%. Hipotesis kedua menunjukkan ada hubungan positif dan signifikan antara dukungan orangtua dengan kemandirian belajar, kontribusi sebesar 31,2\% dan hipotesis ketiga menunjukkan ada hubungan positif dan signifikan antara kepercayaan diri dan dukungan orangtua terhadap kemandirian belajar siswa dengan kontribusi sebesar 41,9\%. Berdasarkan hasil penelitian diharapkan seluruh unsur sekolah mengembangkan kemandirian siswa melalui antara lain penanaman kepercayaan diri bahwa siswa dapat menjadi individu yang mandiri.
\end{abstract}

Kata Kunci : Kepercayaan Diri Siswa; Dukungan Orangtua; Kemandirian Belajar

\section{Abstract}

The purpose of this study was to determine the relationship of self-confidence and support parents with the independence of student learning in SMA Dharma Pancasila Medan. This research is quantitative descriptive research. The population of the study were the students of SMA Dharma Pancasila Medan as many as 472 students consisting of class X as many as 4 classes, class XI as many as 5 classes, and class XII of 5 classes. By using Random Sampling Technique obtained sample of 120 respondents. The result of descriptive analysis shows that in general condition of self confidence, parent support and independence of studying high school students Dharma Pancasila classified. The results of multiple regression analysis of the first hypothesis show that there is a positive and significant relationship between self-confidence with learning independence, the contribution of $27.7 \%$. The second hypothesis shows that there is a positive and significant correlation between parental support and learning independence, contribution of $31,2 \%$ and third hypothesis shows there is positive and significant correlation between self confidence and parent support to student learning independence with contribution equal to 41,9\%. Based on the results of the study is expected all elements of the school to develop student independence through among other self-confidence planting that students can become independent individuals.

Keywords: Student Self Confidence; Parental Support; Learning Independence

How to Cite: Nasution, R. A, Akhyar, S., Aziz, A. (2020). Hubungan Antara Kepercayaan Diri Dan Dukungan Orangtua Dengan Kemandirian Belajar Siswa Di Sma Dharma Pancasila Medan. Tabularasa: Jurnal Ilmiah Magister Psikologi, 2(1) 2020: 40-47

*E-mail: rindanasution16@gmail.com

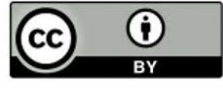

This work is licensed under a Creative Commons Attribution 4.0 


\section{PENDAHULUAN}

Proses belajar merupakan aktivitas yang harus dijalani oleh setiap manusia, bahkan berlangsung sejak seseorang berada dalam kandungan sehingga akhir hayatnya. Melalui proses belajar manusia dapat membekali diri untuk bertahan dalam kehidupannya. Belajar merupakan kunci yang paling penting dalam setiap usaha pendidikan, tanpa aktivitas belajar sesungguhnya pendidikan tidak akan terlaksana (Rani, 2014).

Belajar sebagaimana yang dinyatakan oleh Cronbach dalam Djamarah (2002) adalah suatu aktivitas yang diperlihatkan oleh perubahan tingkah laku sebagai hasil dari pengalaman. Kingskey dalam Djamarah (2008) menyatakan bahwa belajar dalam arti luas adalah suatu proses dimana tingkah laku ditimbulkan atau diubah melalui praktek atau latihan. Demikian pula menurut Slameto (2010) belajar adalah suatu proses usaha yang dilakukan seseorang untuk memperoleh suatu perubahan tingkah laku baru secara keseluruhan, sebagai hasil pengalamannya sendiri dalam interaksi dengan lingkungannya, dengan demikian melalui proses belajar seseorang akan menghasilkan perubahan tingkah laku dalam dirinya. Daryanto (2010) menyatakan secara psikologis belajar merupakan suatu proses perubahan yaitu perubahan tingkah laku sebagai hasil dari interaksi dengan lingkungannya dalam memenuhi kebutuhan hidupnya. Perubahan-perubahan tersebut akan nyata pada seluruh aspek tingkah laku.

Kemandirian adalah unsur penting dalam belajar karena dengan adanya kemandirian, keberhasilan dan prestasi siswa akan lebih mudah diperoleh. Diantara bentuk-bentuk kemandirian siswa adalah kesadaran diri untuk belajar, adanya rasa percaya diri dalam menyesuaikan tugas-tugasnya, tidak mencontoh teman, tidak mencontek buku saat ujian dan memiliki pribadi yang berkualitas. Dimana pribadi yang berkualitas yaitu eksploratif (suka mencari, bertanya, menyelidiki, merumuskan pernyataan, mencari jawaban, peka menangkap gejala alam sebagai bahan untuk mengembangkan diri), kreatif (suka mencari hal-hal yang baru dan berguna, tidak mudah putus asa ketika berhadapan dengan kesulitan, maupun melihat alternative ketika semua jalan buntu) dan integral (mampu melihat dan menghadapi beragam kehidupan dalam keterpaduan yang realitas, utuh dan mengembangkan diri secara utuh) (Pardosi \& Atrizka, 2018; Metia, \& Fenty, 2012; Wati \& Meutia, 2010; Metia, \& Fenty, 2012).

Menurut Fathi (2011) untuk menjadi pribadi mandiri, seorang anak perlu mendapat kesempatan berlatih secara konsisten mengerjakan sesuatu sendiri atau membiasakannya melakukan sendiri tugas-tugas yang sesuai dengan tahapan usianya. Orangtua atau lingkungan tidak perlu bersikap terlalu cemas, terlalu melindungi, terlalu membantu atau bahkan selalu mengambil alih tugas-tugas yang seharusnya dilakukan anak, karena hal ini dapat menghambat proses pencapaian kemandirian anak. Kesempatan untuk belajar mandiri dapat diberikan orangtua atau lingkungan dengan memberikan kebebasan dan kepercayaan pada anak untuk melakukan tugas-tugasnya, orangtua yang bersikap positif dan selalu mendukung anak, praktek kemandirian juga perlu diajarkan kepada anak melalui materi keterampilan hidup dengan konsep-konsep sederhana (Fitriani \& Azhar, 2019: Simorangkir, Asih \& Azhar, 2014; Hasmayni, 2014). 
Berdasarkan hasil observasi dan wawancara dengan Guru Bimbingan Konseling Ibu Susilawati, S.Pd yang peneliti lakukan pada tanggal 21 April 2017 diperoleh informasi berkaitan dengan kemandirian belajar bahwa siswa-siswa kelas XI-IIS2 SMA Dharma Pancasila Medan menganggap kegiatan belajar bukanlah suatu kegiatan yang perlu dilaksanakan secara mandiri, melainkan suatu kegiatan yang baru dilaksanakan jika ada tuntutan akademik seperti jika ada perintah guru dan jika ada ujian. Siswa kurang memiliki rasa tanggung jawab dalam hal belajar seperti mengerjakan PR di sekolah; kurang memiliki inisiatif seperti pada saat guru menerangkan tidak ada siswa yang mau mencatat apa yang diterangkan guru dan terlihat ada 8 orang siswa bercakapcakap pada saat guru menerangkan pelajaran; kurang percaya diri dalam hal menjawab pertanyaan yang diajukan guru (padahal di antara siswa ini terdapat siswa yang termasuk pandai dan mampu untuk menjawab soal tersebut); mereka kurang berani bersaing, dan cenderung kurang ulet dalam mencapai nilai yang lebih baik. Hakim (2002) menjelaskan bahwa rasa percaya diri siswa di sekolah bisa dibangun melalui berbagai macam bentuk kegiatan seperti memupuk keberanian untuk bertanya, peran guru/pendidik yang aktif bertanya pada siswa, melatih berdiskusi dan berdebat, mengerjakan soal di depan kelas, bersaing dalam mencapai prestasi belajar, aktif dalam kegiatan ekstrakurikuler, belajar berpidato, penerapan disiplin yang konsisten, dan memperluas pergaulan yang sehat dan lain-lain.

Dari latar belakang yang telah peneliti uraikan, maka perumusan masalah dalam penelitian ini adalah : apakah ada hubungan kepercayaan diri dengan kemandirian belajar siswa di SMA Dharma Pancasila Medan Tahun 2017? ; apakah ada hubungan dukungan orangtua dengan kemandirian belajar siswa di SMA Dharma Pancasila Medan Tahun 2017? ; dan apakah ada hubungan kepercayaan diri dan dukungan orangtua dengan kemandirian belajar siswa di SMA Dharma Pancasila Medan Tahun 2017, maka tujuan masalah yang ingin dicapai adalah untuk mengetahui adanya hubungan kepercayaan diri dengan kemandirian belajar siswa di SMA Dharma Pancasila Medan Tahun 2017 ; untuk mengetahui adanya hubungan dukungan orangtua dengan kemandirian belajar siswa di SMA Dharma Pancasila Medan Tahun 2017 ; dan untuk mengetahui ada hubungan kepercayaan diri dan dukungan orangtua dengan kemandirian belajar siswa di SMA Dharma Pancasila Medan Tahun 2017.

\section{METODE PENELITIAN}

Penelitian ini menggunakan pendekatan deskriptif kuantitatif. Ditinjau dari teknik samplingnya menggunakan pendekatan sampel. Ditinjau dari timbulnya variabel menggunakan penelitian non-eksperimen. Selanjutnya, jika ditinjau dari pola-pola atau sifat penelitian non eksperimen termasuk penelitian korelasi.

Penelitian ini dilaksanakan di SMA Dharma Pancasila Medan pada tanggal 15 sampai dengan 17 Mei 2017. Populasi dalam penelitian ini siswa SMA Dharma Pancasila Medan kelas X, XI, XII sebanyak 14 kelas dengan jumlah siswa 472 orang. Dengan menggunakan Teknik Random Sampling berdasarkan pengambilan sampel menurut Arikunto (2010), untuk menentukan besarnya sampel dalam penelitian ini, peneliti menggunakan 25\% (duapuluh lima persen) dari jumlah populasi sehingga diperoleh sampel sebanyak 120 responden. 
Nasution, R. A, Akhyar, S., Aziz, A. Hubungan Antara Kepercayaan Diri Dan Dukungan Orangtua Dengan

Teknik pengumpulan data dilakukan dengan menggunakan skala ukur kepercayaan diri, skala dukungan orangtua dan skala kemandirian belajar dengan aspek-aspek sebagai berikut:

1. Kepercayaan diri

Aspek-aspek kepercayaan diri dalam penelititan ini disusun menurut De Angelis (2003) yaitu aspek tingkah laku, aspek emosional dan aspek spiritual.

2. Dukungan orangtua

Aspek-aspek dukungan orangtua dalam penelitian ini disusun menurut Friedman (2008) adalah dukungan informasional, dukungan penilaian, dukungan instrumental dan dukungan emosional.

3. Kemandirian belajar

Aspek-aspek kemandirian belajar dalam penelitian ini disusun menurut Masrun dalam Juliani (2005) adalah memiliki kebebasan, mampu mengambil inisiatif, memiliki control diri (mampu mengendalikan tindakan), progresif dan ulet, kemantapan diri, kepercayaan diri dan memiliki sikap eksploratif.

Alat ukur skala kepercayaan diri, dukungan orangtua dan kemandirian belajar siswa dalam penelitian ini berdasarkan format skala Likert dengan 4 (empat) pilihan jawaban yang terbagi dalam dua jenis pernyataan yaitu pernyataan positif dan pernyataan negatif. Untuk setiap pernyataan positif yang dijawab Sangat Setuju mendapat skor 4, Setuju mendapat skor 3, Kurang Setuju mendapat skor 2 dan jawaban Tidak Setuju mendapat skor 1. Untuk pernyataan negatif yang dijawab Sangat Setuju mendapat skor 1, Setuju mendapat skor 2, Kurang Setuju mendapat skor 3 dan Tidak Setuju mendapat skor 4.

Metode analisis data yang digunakan untuk menguji hipotesis penelitian adalah Analisis Regresi Berganda yaitu untuk melihat hubungan antara kepercayaan diri dan dukungan orangtua dengan kemandirian belajar siswa di SMA Dhama Pancasila Medan dan menunjukkan variabel yang dominan dalam mempengaruhi variabel terikat dan mengetahui sumbangan efektif dari masing-masing variabel.

\section{HASIL DAN PEMBAHASAN}

Dari hasil analisis data penelitian berdasarkan butir pernyataan terhadap variabel kepercayaan diri, dukungan orangtua dan kemandirian belajar maka diperoleh nilai korelasi antara skor item dengan skor total. Kemudian nilai ini dibandingkan dengan nilai r-tabel. Pada taraf signifikan 0,05 dengan uji 2 sisi dan jumlah data (n) $=40$, maka didapatkan r-tabel sebesar 0,312. Diketahui bahwa terdapat 31 pernyataan pada skala kemandirian belajar yang memiliki nilai r-hitung $>0,312$ (valid) dengan nilai Alpha Cronbach sebesar 0,798 dan dinyatakan reliabel. Pada skala kepercayaan diri terdapat 35 pernyataan yang memiliki nilai r-hitung $>0,312$ (valid) dengan nilai Alpha Cronbach sebesar 0,924 dan dinyatakan reliabel. Pada skala dukungan orangtua terdapat 41 pernyataan yang memiliki nilai r-hitung >0,312 (valid) dengan nilai Alpha Cronbach sebesar 0,906 dan dinyatakan reliabel.

Adapun sebaran frekuensi data untuk skala disiplin, motivasi belajar, dan kemandirian belajar siswa-siswi SMA Dharma Pancasila Medan adalah sebagai berikut : 
Tabel 1.Frekuensi Responden berdasarkan Variabel Penelitian pada Siswa SMA Dharma Pancasila Medan

\begin{tabular}{|c|c|c|c|}
\hline Katagori & Rentang Nilai & $\mathbf{F}$ & $\%$ \\
\hline \multicolumn{4}{|c|}{ 1. Kepercayaan Diri } \\
\hline Rendah & $<82$ & - & - \\
\hline Sedang & $82-97$ & 15 & 12.5 \\
\hline \multirow[t]{2}{*}{ Tinggi } & $>97$ & 105 & 87.5 \\
\hline & Jumlah & 120 & 100.0 \\
\hline \multicolumn{4}{|c|}{ 2. Dukungan Orangtua } \\
\hline Rendah & $<100$ & 2 & 1.7 \\
\hline Sedang & $100-130$ & 60 & 50.0 \\
\hline \multirow{2}{*}{ Tinggi } & $>130$ & 58 & 48.3 \\
\hline & Jumlah & 120 & 100.0 \\
\hline \multicolumn{4}{|c|}{ dirian Belajar } \\
\hline Rendah & $<81$ & 10 & 8.3 \\
\hline Sedang & $81-102$ & 83 & 69.2 \\
\hline \multirow[t]{2}{*}{ Tinggi } & $>102$ & 27 & 22.5 \\
\hline & Jumlah & 180 & 100.0 \\
\hline
\end{tabular}

Dari hasil penelitian tersebut di atas diketahui bahwa rata-rata responden memiliki kepercayaan diri tinggi yaitu sebanyak 105 responden (87,5\%), dukungan orangtua dalam katagori sedang yaitu sebanyak 60 responden (50\%) dan kemandirian belajar tergolong sedang yaitu sebanyak 83 responden $(69,2 \%)$. Hal ini dapat dilihat pada tabel di bawah ini.

Sebelum data dianalisis dengan teknik Analisis Regresi Berganda, terlebih dahulu dilakukan uji asumsi normalitas dan linieritas data. Uji normalitas dalam penelitian ini dilakukan dengan menggunakan uji Kolmogorov-Smirnov satu sampel. Dasar pengambilan keputusan dalam uji normalitas yakni jika nilai signifikansi lebih besar dari 0,05 maka data tersebut berdistribusi normal. Sebaliknya, jika nilai signifikansi lebih kecil dari 0,05 maka data tersebut tidak berdistribusi normal. Hasil uji asumsi normalitas dapat dilihat pada tabel dibawah ini :

Tabel 2. Hasil Uji Normalitas

\begin{tabular}{cccc}
\hline Variabel & Kolmo gorov-Smirnov Z & $\mathbf{P}$ & Ket. \\
\hline Kepercayaan Diri & 0,917 & 0,370 & Normal \\
Dukungan Orangtua & 0,538 & 0,935 & Normal \\
Kemandirian belajar & 0,764 & 0,604 & Normal \\
\hline
\end{tabular}

Sumber: Hasil Penelitian (2017)

Berdasarkan tabel di atas, diketahui bahwa uji asumsi normalitas sebaran terhadap variabel kemandirian belajar menghasilkan p-value $>0,05$, sehingga dapat disimpulkan bahwa data yang diuji berdistribusi normal.

Kaidah yang digunakan untuk pada uji linieritas untuk mengetahui linier atau tidak hubungan antara kedua variabel penelitian adalah jika p-value $<0,05$ maka hubungan kedua variabel dinyatakan linier. Sebaliknya jika p-value $>0,05$ maka hubungan kedua variabel tidak linier. Hasil uji linieritas disajikan dalam tabel 3 di bawah ini:

Tabel 3. Hasil Uji Linieritas 
Nasution, R. A, Akhyar, S., Aziz, A. Hubungan Antara Kepercayaan Diri Dan Dukungan Orangtua Dengan

\begin{tabular}{cccl}
\hline Uji Linieritas & F & p-value & Hasil \\
\hline$X 1-Y$ & 47.581 & 0,000 & Linier \\
$X 2-Y$ & 57.110 & 0,000 & Linier \\
\hline
\end{tabular}

Sumber: Hasil Penelitian (2017)

Dari tabel 3 hasil uji linieritas di atas menunjukkan bahwa p-value untuk masingmasing variabel bebas $<0,05$, maka dapat dikatakan bahwa kedua variabel bebas yaitu kepercayaan diri dan dukungan orangtua memenuhi syarat linieritas.

Untuk mengetahui kondisi kepercayaan diri, dukungan orangtua dan kemandirian belajar pada siswa SMA Dharma Pancasila Medan, maka perlu dibandingkan antara mean hipotetik dengan mean empirik, dengan memperhatikan besarnya bilangan SD (standard deviasi) dari masing-masing variabel. Dari besarnya bilangan SD tersebut, maka diperoleh kesimpulan apabila mean hipotetik < mean empirik, dimana selisihnya melebihi bilangan satu SD, maka dinyatakan bahwa variabel tersebut tergolong tinggi dan apabila mean hipotetik > mean empirik, dimana selisihnya melebihi bilangan satu SD, maka dinyatakan bahwa variabel tersebut tergolong rendah. Mean hipotetik untuk setiap variabel dapat diketahui berdasarkan jumlah butir jawaban responden yang valid.

Tabel 4. Hasil Analisis Statistik Deskriptif

\begin{tabular}{ccccc}
\hline & \multirow{2}{*}{ SD } & \multicolumn{2}{c}{ Nilai Rata-Rata } & Ket \\
\cline { 2 - 5 } & & Empiris & Hipotetik & \\
\hline X1 & 7.947 & 99.49 & 87,5 & Tinggi \\
X2 & 14.992 & 115.45 & 102,5 & Tinggi \\
Y & 10.770 & 91.28 & 77,5 & Tinggi \\
\hline
\end{tabular}

Sumber: Hasil Penelitian (2017)

Oleh karena nilai rata-rata empiris lebih besar dari nilai rata-rata hipotetik dan selisih antara nilai rata-rata empiris dengan nilai rata-rata hipotetik melebihi bilangan satu SD maka dapat disimpulkan bahwa ketiga variabel tersebut tergolong tinggi.

Berdasarkan hipotesis penelitian melalui hasil pengujian product moment dan hasil analisis regresi berganda antara variabel bebas (kepercayaan diri dan dukungan orangtua) dengan variabel terikat (kemandirian belajar) maka diperoleh hasil penelitian pada tabel di bawah ini :

Tabel 5. Hasil Hipotesis Penelitian

\begin{tabular}{cccc}
\hline Variabel & F & R & p-value \\
\hline $\mathrm{X} 1-\mathrm{Y}$ & 45,309 & $0,527^{\mathrm{a}}$ & 0,000 \\
$\mathrm{X} 2-\mathrm{Y}$ & 53,496 & $0,559^{\mathrm{a}}$ & 0,000 \\
$\mathrm{X} 1, \mathrm{X} 2-\mathrm{Y}$ & 42,112 & $0,647^{\mathrm{a}}$ & 0,000 \\
\hline
\end{tabular}

Sumber : Hasil Penelitian (2017)

Dari hasil hipotesis penelitian pada tabel 5 di atas, pada hipotesis pertama diperoleh hasil bahwa ada hubungan yang signifikan antara kepercayaan diri dengan kemandirian belajar pada siswa dengan koefisien korelasi sebesar 0,527 dan p<0,000. 
Kemudian pada hipotesis kedua diperoleh hasil bahwa ada hubungan yang signifikan antara dukungan orangtua dengan kemandirian belajar dengan nilai koefisien korelasi sebesar 0,559 dan $\mathrm{p}<0.000$. Selanjutnya pada hipotesis ketiga diperoleh hasil bahwa ada hubungan yang signifikan antara kepercayaan diri dan dukungan orangtua dengan kemandirian belajar yang ditunjukkan oleh nilai koefisien korelasi sebesar 0,647 dengan $\mathrm{p}<0,000$.

Tabel 6. Kontribusi Variabel Kepercayaan Diri, Dukungan orangtua dan Kemandirian belajar Siswa SMA Dharma Pancasila Medan

\begin{tabular}{cccc}
\hline Korelasi & $\mathrm{R}^{2}$ & Sig. & Ket \\
\hline $\mathrm{X} 1-\mathrm{Y}$ & 0,277 & 0,000 & Rendah \\
$\mathrm{X} 2-\mathrm{Y}$ & 0,312 & 0,000 & Rendah \\
$\mathrm{X} 1, \mathrm{X} 2-\mathrm{Y}$ & 0,419 & 0,000 & Sedang \\
\hline
\end{tabular}

Dari tabel di atas diketahui bahwa kepercayaan diri memiliki kontribusi yang rendah dalam menjelaskan kemandirian belajar siswa yaitu sebesar 27,\%, begitu pula dukungan orangtua dengan kemandirian belajar yaitu sebesar 31,2\%. Secara bersamasama kepercayaan diri dan dukungan orangtua memiliki kontribusi yang sedang dalam menjelaskan kemandirian belajar yaitu sebesar 41,9\%.

Hipotesis penelitian ini membuktikan bahwa ada hubungan positif dan signifikan antara kepercayaan diri dan dukungan orangtua dengan kemandirian belajar pada siswa di SMA Dharma Pancasila dapat diterima. Hasil penelitian ini sejalan dengan penelitian yang telah dilakukan oleh Rani (2014) dalam penelitiannya yang menyatakan bahwa terdapat hubungan positif dan signifikan antara kepercayaan diri dan pola asuh demokrasi dengan kemandirian belajar siswa kelas XI IPS SMAN 6 Padang.

\section{SIMPULAN}

Dari hasil penelitian, maka kesimpulan yang dapat dikemukakan dalam penelitian ini adalah sebagai berikut: Ada hubungan positif dan signifikan antara kepercayaan diri dengan kemandirian belajar siswa di SMA Dharma Pancasila Medan. Kepercayaan diri memberikan kontribusi sebesar 27,7\% dalam menjelaskan kemandirian belajar pada siswa SMA Dharma Pancasila Medan. Ada hubungan yang positif dan signifikan antara dukungan orangtua dengan kemandirian belajar siswa di SMA Dharma Pancasila Medan. Dukungan orangtua memberikan kontribusi sebesar $31,2 \%$ dalam menjelaskan kemandirian belajar pada siswa SMA Dharma Pancasila Medan. Ada hubungan yang positif dan signifikan antara kepercayaan diri dan dukungan orangtua dengan kemandirian belajar siswa di SMA Dharma Pancasila. Kontribusi kepercayaan diri dan dukungan orangtua sebesar $41,9 \%$ dalam menjelaskan kemandirian belajar pada siswa SMA Dharma Pancasila Medan.

\section{DAFTAR PUSTAKA}

Arifiati, R.F. (2013). Hubungan antara Dukungan Sosial Keluarga dan Kepercayaan Diri dengan Kemandirian Belajar pada Siswa SMP Muhammadiyah I Surakarta tahun 2012/2013. Naskah 
Nasution, R. A, Akhyar, S., Aziz, A. Hubungan Antara Kepercayaan Diri Dan Dukungan Orangtua Dengan

Publikasi. Program Magister Sains Psikologi. Program Pascasarjana Universitas Muhammadiyah Surakayat.

Arikunto, S. (2010). Prosedur Penelitian. Rineka Cipta. Bandung.

Daryanto. (2010). Belajar dan Mengajar. Cetakan 1. Bandung: Yrama Widya.

De Angelis, B. (2003). Percaya Diri: Sumber Sukses dan Kemandirian. Cetakan Ketujuh. Jakarta: Gramedia Pustaka Umum. Friedman. M.M. 2008. Keperawatan Keluarga: Teori dan Praktik. Alih bahasa, Ina DRL., Yoakim A, Editor, Yasmin A., Setiawan, Monica E., Edisi 3. Jakarta: EGC.

Djamarah, S.B. (2002). Psikologi Belajar. Jakarta: Rineka Cipta.

Djamarah. (2008). Psikologi Belajar. Jakarta: Rineka Cipta.

Fathi. (2011). Mendidik Anak dengan Al - Qur'an Sejak Janin. Jakarta: Grasindo.

Fitriani, E., \& Azhar, A. (2019). Layanan Informasi Berbasis Focus Group Discussion (FGD) dalam Meningkatkan Kepercayaan Diri Siswa. Analitika: Jurnal Magister Psikologi UMA, 11(2), 82 - 87. doi:https://doi.org/10.31289/analitika.v11i2.2552

Friedman. M.M. (2008). Keperawatan Keluarga: Teori dan Praktik. Alih bahasa, Ina DRL., Yoakim A, Editor, Yasmin A., Setiawan, Monica E., Edisi 3. Jakarta: EGC.

Hakim, T. (2002). Mengatasi Rasa Tidak Percaya Diri. Jakarta: Puspa Swara

Hasmayni, B, (2014), Hubungan Antara Kepercayaan Diri Dengan Penyesuaian Diri Remaja, Analitika: 6 (2): $91-104$

Masrun, dkk. (2006). Studi Mengenai Kemandirian Pada Penduduk di Tiga Suku Jawa, Batak dan Bugis. Laporan Penelitian. Yogyakarta: Kantor Menteri Negara dan Lingkungan Hidup. Fakultas Psikologi UGM

Metia, C., Fenty Z., (2012), Hubungan Dukungan Sosial Orangtua dan Motivasi Belajar dengan Kemandirian Belajar, Analitika: 4 (1): 16-23

Metia, C., Fenty Z., (2012), Hubungan Dukungan Sosial Orangtua dan Motivasi Belajar dengan Kemandirian Belajar, Analitika: 4 (1): 16-23

Pardosi, N., \& Atrizka, D. (2018). Kemandirian Belajar Ditinjau dari Dukungan Sosial Orangtua pada Siswa Sekolah Menengah Atas. Analitika: Jurnal Magister Psikologi UMA, 10(2), 97 - 103. doi:https://doi.org/10.31289/analitika.v10i2.2020

Rani, A. (2014). Hubungan Kepercayaan Diri dan Pola Asuh Demokrasi dengan Kemandirian Belajar Siswa SMA Negeri 1 Tanah Jambo Aye Kabupaten Aceh Utara. Tesis. Program Studi Magister Psikologi. Program Pascasarjana Universitas Medan Area

Simorangkir, N.R., Asih M., Azhar A., (2014) Kontribusi Komunikasi Persuasif Guru Terhadap Kepercayaan Diri Dan Motivasi Belajar, Analitika: 6 (2): 60

Slameto. (2010). Belajar dan Faktor-Faktor yang Mempengaruhinya. Rineka Cipta. Jakarta.

Wati S, P., Cut M., (2010), Hubungan antara Dukungan Sosial Keluarga dan Self Efficacy dengan Kemandirian Belajar pada Siswa SMKN 2 Medan, Analitika: 2 (2): 45-54 